\title{
PERKIRAAN LAMA WAKTU KEMATIAN DENGAN MENGGUNAKAN MODEL MODIFIKASI HUKUM PENDINGINAN NEWTON
}

\author{
GUSTINA VIRNY \\ Jurusan Matematika, \\ Fakultas Matematika dan Ilmu Pengetahuan Alam, Universitas Andalas, \\ Kampus UNAND Limau Manis Padang, Indonesia. \\ email : gutinavirny@gmail.com
}

\begin{abstract}
Abstrak. Makalah ini membahas model modifikasi hukum pendinginan Newton untuk memperkirakan lama waktu kematian. Untuk mencari solusi dari model modifikasi hukum pendinginan Newton, digunakan metode pemisahan variabel. Solusi dari modifikasi hukum pendinginan Newton ini diplot dengan menggunakan data berat badan sehingga diperoleh grafik yang menunjukkan bahwa semakin besar berat badan seseorang maka proses pendinginan suhu tubuhnya akan lebih lama sehingga lama waktu kematiannya juga akan lebih lama.
\end{abstract}

Kata Kunci: hukum pendinginan Newton, metode pemisahan variabel, lama waktu kematian

\section{Pendahuluan}

Memperkirakan saat kematian yang mendekati ketepatan mempunyai arti penting, khususnya bila dikaitkan dengan proses penyelidikan. Dengan demikian penyelidikan dapat lebih terarah dan selektif di dalam melakukan pemeriksaan terhadap para tersangka pelaku tindak pidana. Seorang ahli forensik harus mampu mendeskripsikan penyebab dan mekanisme kematian seseorang. Mekanisme kematian timbul akibat abnormalitas dari aspek biokimia dan fisiologi tubuh yang berujung pada kematian.

Hukum pendinginan Newton adalah hukum ilmiah yang teruji dan benar. Tetapi percobaan Rainy yang meneliti fenomena pendinginan tidak setuju, karena Newton merumuskan hukum untuk pendinginan benda-benda yang memiliki kerapatan seragam. Sedangkan tubuh manusia terdiri dari organ, tulang, daging dan pembuluh darah, dimana semuanya memiliki perbedaan kerapatan partikelnya masingmasing. Sementara itu, Rainy memperoleh hasil yang berbeda dari penelitian terhadap tubuh manusia, dia juga melakukan investigasi laboratorium untuk menetapkan interval kepercayaan statistik, yaitu $95 \%$ yang memberikan nilai minimum dan nilai maksimum untuk waktu kematian dengan menggunakan model Newton [1].

Waktu kematian bisa menjadi bagian penting dari informasi dalam beberapa kasus, terutama yang melibatkan investigasi kriminal atau asuransi. Menjelang akhir abad kesembilan belas, hukum pendinginan Newton menggunakan data suhu tubuh yang diperoleh dari pemeriksaan mayat dan digunakan untuk membuat perkiraan 
yang lebih akurat. Sementara berdasarkan prinsip ilmiah menghasilkan perkiraan yang lebih baik, hukum Newton tidak benar-benar menggambarkan pendinginan tubuh manusia yang tidak homogen. Penelitian ini akan membahas kembali kajian pada referensi [1] tentang model pendinginan yang lebih akurat berdasarkan kajian Marshall dan Hoare.

\section{Landasan Teori}

\subsection{Persamaan Diferensial Biasa Orde Satu}

Persamaan diferensial biasa orde satu secara umum dapat dinyatakan dalam bentuk

$$
\frac{d y}{d x}=f(x, y)
$$

Jika $f(x, y)$ dapat dinyatakan dalam bentuk $f(x, y)=g(x) . h(y)$ maka penyelesaian persamaan diferensial biasa tersebut dapat dilakukan dengan cara memisahkan variabelnya sehingga faktor $y$ bisa kita kumpulkan dengan $d y$ dan faktor $x$ dengan $d x[5]$.

\subsection{Hukum Pendinginan Newton}

Pada tahun 1868, Rainy, Profesor Yurisprudensi Medis (Forensik) di Universitas Glasgow, mengakui bahwa karyanya tidak akan menjawab pertanyaan untuk menetapkan waktu kematian dengan akurasi yang lengkap. Hal ini terutama berlaku untuk pekerjaan yang dilakukan di lapangan, bukan yang dilakukan di laboratorium. Karena salah satu kondisi lapangan yang tidak disertakan dalam analisis Rainy adalah suhu lingkungan yang tidak konstan. Sebuah fenomena yang ditunjukkan Rainy adalah pendinginan tubuh selama periode post-mortem sangat berbeda dari prediksi hukum Newton tentang pendinginan. Kurvanya jauh lebih datar. Daerah dari kurva tersebut dikenal sebagai Rainy Plateau [4].

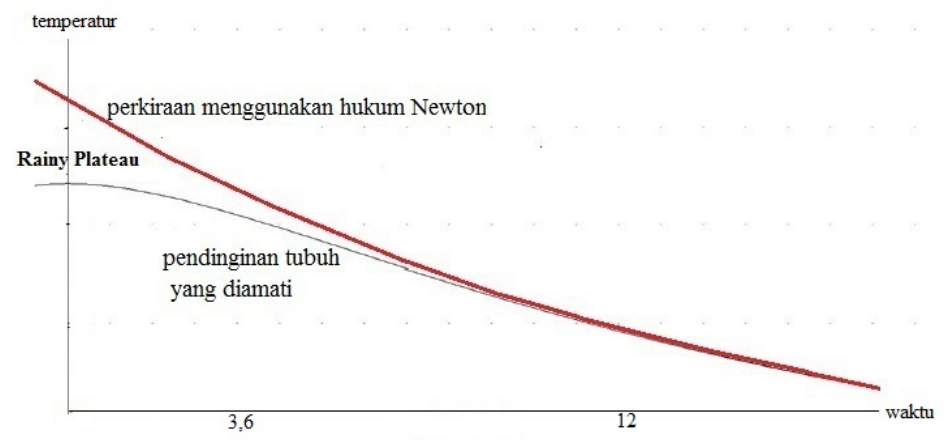

Gambar 1. Perbandingan kurva yang dihasilkan dari data aktual dengan kurva berdasarkan hukum pendinginan Newton

Gambar 1 menjelaskan tentang pendinginan tubuh dari mayat seorang pria dengan berat badan $70 \mathrm{~kg}$ menggunakan data dalam penyelidikan Rainy dan yang 
diprediksi oleh hukum pendinginan Newton mengenai pendinginan selama 20 jam periode waktu post-mortem. Waktu ketika kurva pendinginan Newton (plot atas) memiliki titik koordinat $y$ dari $37,1^{0} C$, yaitu suhu tubuh normal yang diasumsikan dan memperoleh hasil 3,6 jam setelah proses pendinginan yang sebenarnya (plot bawah). Sehingga dapat disimpulkan bahwa dalam kasus hukum pendinginan Newton akan memberikan perkiraan 3,6 jam lebih lambat dari pada waktu kematian sebenarnya.

Model hukum pendinginan Newton menggunakan persamaan diferensial untuk membedakan antara suhu tubuh dengan suhu lingkungannya, yang dinyatakan dalam bentuk :

$$
\theta^{\prime}(t)=-\beta \theta(t)
$$

dimana $\theta(t)$ adalah selisih antara suhu tubuh dan suhu lingkungan, dan $\beta$ adalah sebuah konstanta.

\section{Pembahasan}

\subsection{Model Marshall dan Hoare}

Marshall dan Hoare mengajukan modifikasi pada model Newton,yang dinyatakan dalam bentuk:

$$
\theta^{\prime}(t)=-\beta \theta(t)-\gamma e^{-\alpha t}
$$

dimana $\beta$ adalah konstanta dalam model Newton dan $\gamma e^{-\alpha t}$ adalah suku yang berhubungan dengan pendinginan organ dalam tubuh setelah kematian.

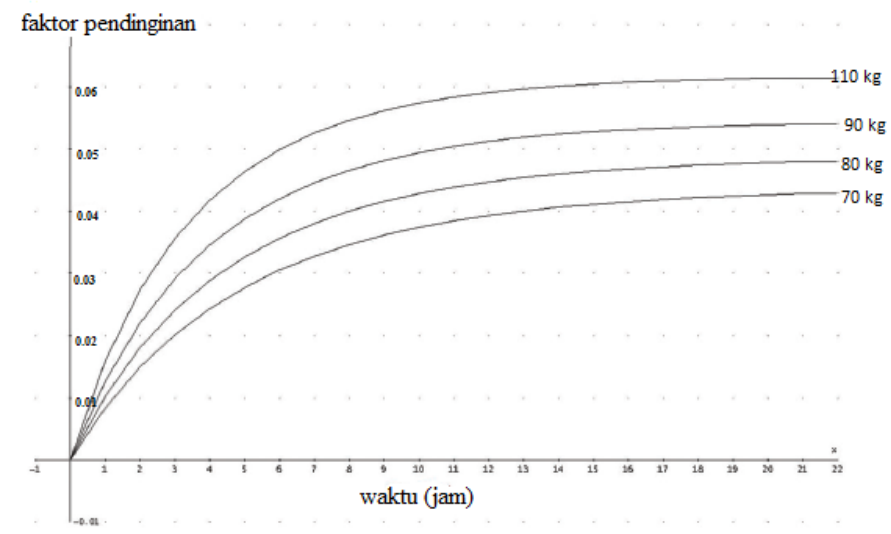

Gambar 2. Grafik Marshall dan Hoare dari kurva perbedaan suhu

Marshall dan Hoare mengamati tingkat pendinginan tubuh yang terbaik digambarkan pada grafik yang ditunjukkan pada Gambar 2, yang didasarkan pada data Marshall dan Hoare [6]. Berat jenazah dalam data Marshall dan Hoare dimulai dengan kurva bawah, masing-masing adalah: 70 kg, 80 kg, 90 kg, 110 kg. 
Bukti eksperimen ini bertentangan dengan pernyataan hukum pendinginan Newton, yang menegaskan bahwa rasio perbedaan antara suhu tubuh dan suhu sekitar dan laju pendinginan dari kuantitas ini akan bernilai konstan. Gambar 2 menunjukkan bahwa rasionya adalah 0 pada saat kematian, dan awalnya meningkat dengan kecepatan bergantung pada berat tubuh, lalu secara asimtotik mendekati laju pendinginan konstan.

Setelah dilakukan penghitungan terhadap model Marshall dan Hoare sebelumnya, sehingga diperoleh solusi dari model Marshall dan Hoare adalah

$$
\theta(t)=\frac{c(\beta-\alpha)+\gamma}{\beta-\alpha} e^{-\beta t}-\frac{\gamma}{\beta-\alpha} e^{-\alpha t}
$$

\subsection{Model Claus Henssge}

Claus Henssge, seorang Profesor Forensic Medicine di Universitas Essen, memodifikasi persamaan Marshall dan Hoare menjadi sebuah persamaan dengan dua konstanta yang tidak diketahui, yaitu [6]

$$
Q(t)=\frac{T(t)-L}{T(0)-L}=A e^{-B t}+(1-A) e^{\frac{A B}{A-1} t} .
$$

dimana :

$$
\begin{aligned}
T(t) & : \text { suhu tubuh pada saat } \mathrm{t}, \\
T(0) & : \text { suhu tubuh pada saat kematian } t=0, \\
L & : \text { suhu lingkungan, } \\
A, B & : \text { konstanta yang akan ditentukan. }
\end{aligned}
$$

(1) Konstanta B.

Henssge melakukan penelitian untuk menentukan nilai A dan B. Yang paling mudah untuk ditentukan adalah nilai B karena berkaitkan dengan bagian kurva pendinginan yang langsung berhubungan dengan koefisien pendinginan dalam hukum pendinginan Newton. Henssge[2] menemukan bahwa nilai B sangat berkorelasi dengan berat badan seseorang dan dapat dinyatakan dengan

$$
B(w)=-1,2851 w^{-0,625}+0,0284,
$$

dimana w adalah berat badan $(\mathrm{kg})$.

(2) Konstanta A.

Untuk menentukan nilai dari konstanta A, akan dibagi dua kasus:

(a) Nilai konstanta A untuk pendinginan tubuh pada suhu lingkungan kurang dari $23^{0} \mathrm{C}$.

$$
Q(t)=1,25 e^{B(w) \cdot t}-0,25 e^{5 \cdot B(w) \cdot t}
$$

(b) Nilai konstanta A untuk pendinginan tubuh pada suhu lingkungan lebih dari $23^{0} \mathrm{C}$.

$$
Q(t)=1,11 e^{B(w) \cdot t}-0,11 e^{10 \cdot B(w) \cdot t} .
$$


Dalam upaya memudahkan penyelidikan di tempat pemeriksa mayat, maka untuk membuat perkiraan yang lebih akurat tentang waktu kematian, pilihan yang lebih baik adalah dengan menggunakan grafik dari persamaan (3.5) dan persamaan (3.6) yang menampilkan solusi untuk berat badan yang berbeda. Grafik ini dapat digambarkan sebagai berikut :

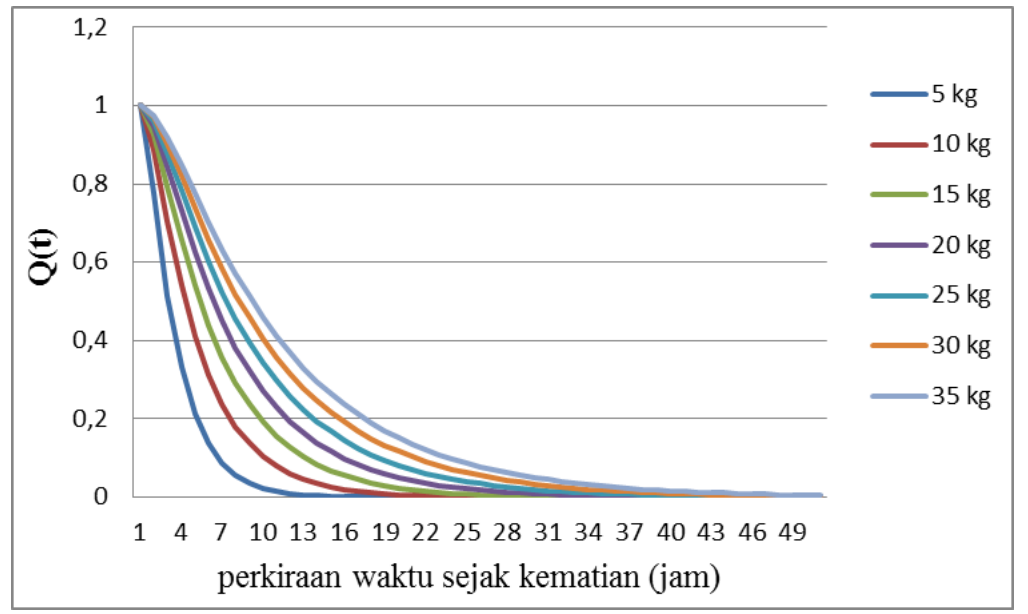

Gambar 3. Grafik Persamaan (3.5) untuk berat dari $5 \mathrm{~kg}$ sampai $35 \mathrm{~kg}$ (urutan naik).

Gambar 3 menjelaskan tentang grafik hasil plot dari berat badan (kg), waktu kematian(jam), dan kemungkinan pendinginan suhu tubuh mayat $(\mathrm{Q}(\mathrm{t}))$ untuk berat badan $5 \mathrm{~kg}$ sampai $35 \mathrm{~kg}$.

Setelah dilakukan penghitungan terhadap berat badan mayat, yaitu $B(w)$ selanjutnya dilakukan juga penghitungan terhadap kemungkinan pendinginan suhu tubuh mayat, yaitu $Q(t)$ sehingga didapatkan hasil plot data seperti tertera pada Gambar 3.

Jika seseorang dengan berat badan $10 \mathrm{~kg}$ dan telah mengalami proses kemungkinan pendinginan suhu tubuh atau kemungkinan kehilangan panas sehingga tersisa 0,20107 atau 20\% di tubuh mayat tersebut saat dilakukan penyelidikan, maka dapat diperkirakan waktu yang wajar sejak kematian mayat tersebut adalah 7,5 jam.

Dengan menggunakan grafik dari Gambar 3, Gambar 4, Gambar 5, dan Gambar 6 , sebagian besar penyelidikan forensik dapat dengan cepat menentukan perkiraan waktu sejak kematian seseorang di tempat kejadian dan apabila mereka juga memiliki salinan Gambar 3 dan Gambar 4 untuk suhu lingkungan kurang dari $23^{\circ} \mathrm{C}$ dan Gambar 5 dan Gambar 6 untuk suhu lingkungan di atas $23^{\circ} C$.

\section{Kesimpulan}

Pada penelitian ini telah didapatkan kesimpulan, yaitu untuk menentukan waktu sejak kematian seseorang bisa diperkirakan dengan melihat grafik hasil plot dari berat badan $(\mathrm{kg})$ dan kemungkinan pendinginan suhu tubuh mayat $(\mathrm{Q}(\mathrm{T}))$, maka dapat 


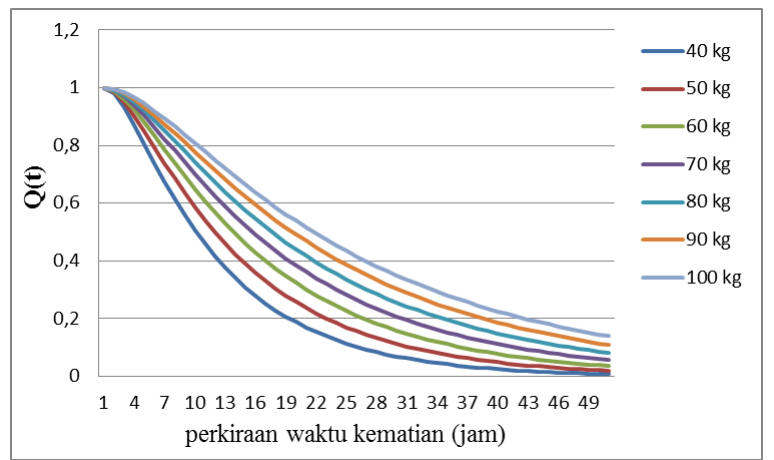

Gambar 4. Grafik Persamaan (3.5) untuk berat dari $40 \mathrm{~kg}$ sampai $100 \mathrm{~kg}$ (urutan naik).

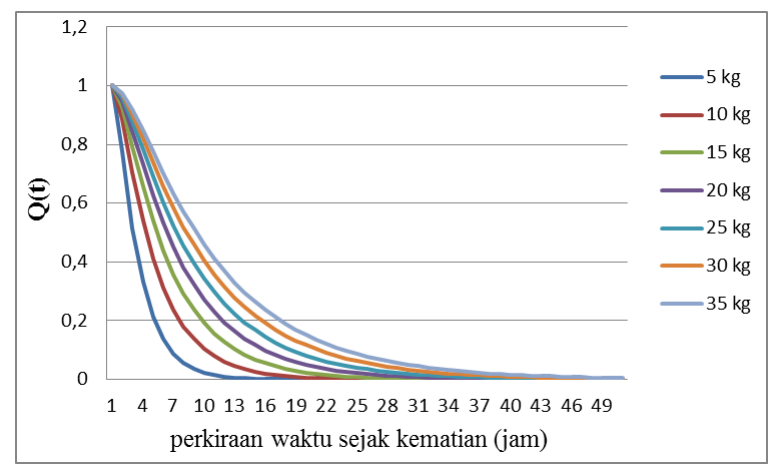

Gambar 5. Grafik Persamaan (3.6) untuk berat dari $5 \mathrm{~kg}$ sampai $35 \mathrm{~kg}$ (urutan naik).

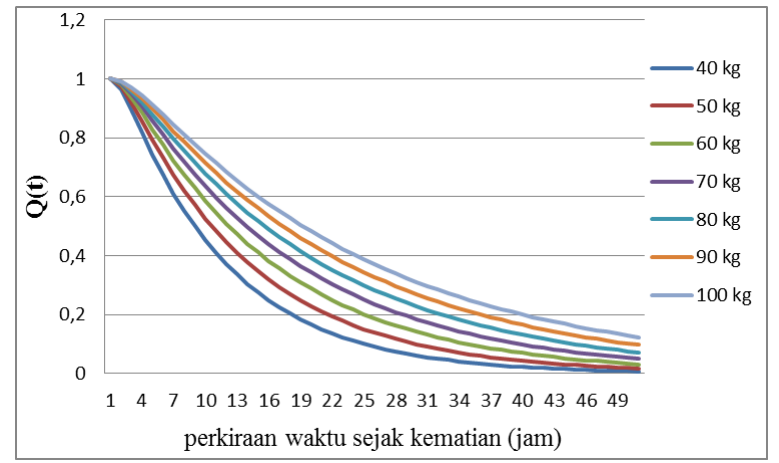

Gambar 6. Grafik Persamaan (3.6) untuk berat dari $40 \mathrm{~kg}$ sampai $100 \mathrm{~kg}$ (urutan naik).

disimpulkan bahwa semakin besar berat badan seseorang maka proses pendinginan suhu tubuhnya akan lebih lama sehingga lama waktu kematiannya juga akan lebih lama. Begitu juga sebaliknya, semakin kecil berat badan seseorang maka proses pendinginan suhu tubuhnya akan lebih cepat dan perkiraan lama waktu kematian- 
104 Gustina Virny

nya juga akan lebih cepat.

\section{Ucapan Terima kasih}

Penulis mengucapkan Terima kasih kepada bapak Efendi, M.Si, bapak Dr. Mahdhivan Syafwan, bapak Dr. Effendi, ibu Radhiatul Husna, M.Si dan Bapak Dr. Ahmad Iqbal Baqi, yang telah memberikan masukan dan saran sehingga makalah ini dapat diselesaikan dengan baik.

\section{Daftar Pustaka}

[1] Taylor and Francis. 2014. Beyond Newton's Law of Cooling-Estimation of Time Since Death. University of Connecticut, London.

[2] Henssge, C. 1988. Death Time Estimation in Case Work I. The Rectal Temperature Time of Death Nomogram. Forensic. Sci. Int. 38, pp. $209-236$.

[3] Knight, B. 1995. The Estimation of the Time Since Death in the Early Postmortem Period. Edward Arnold, London

[4] Rainy, H. 1868. On the Cooling of Dead Bodies as Indicating the Length of Time Since Death. Glasgow Med. J. 1, pp. $323-330$

[5] Boyce, W.E and Prime. 2009. Elementary Differential Equations and Boundary Value Problems. John Wiley Sons, New York.

[6] Brown, A and Marshall, T.K. 1974. Body Temperature As A Means Of Estimating The Time Of Death. Elsevier Sequoia S.A., Lausanne.

[7] Wazwaz, A.M. 2009. Partial Differential Equation and Solitary Waves Theory. Springer, Berlin Heidelberg. 